\title{
Kadar Protein Pada Tempe Bersumber Dari Kacang Kedelai Hasil Perendaman Bonggol Nanas (Ananas comosus (Linn) Merrill)
}

\author{
Yenni Aulia Putri', Elita Agustina1, Ria Ceriana ${ }^{2, *}$ \\ ${ }^{1}$ Prodi PBL FTK, UIN Ar-Raniry, Kota Banda Aceh, Indonesia \\ ${ }^{2}$ Prodi DIII Farmasi, Akademi Farmasi YPPM Mandiri, Kota Banda Aceh, Indonesia \\ Email: cherry4n4@yahoo.com
}

\begin{abstract}
Abstrak-Nanas adalah salah satu buah yang dikonsumsi oleh masyarakat. Nanas menghasilkan limbah berupa bonggol nanas yang dibuang secara percuma. Bonggol nanas dapat dimanfaatkan untuk media perendaman biji kedelai dalam proses pembuatan tempe. Tujuan penelitian ini adalah untuk mengetahui pengaruh bonggol nanas untuk meningkatkan kadar protein tempe, untuk mengetahui lama perendaman biji kedelai dalam perasan bonggol nanas yang efektif meningkatkan kadar protein tempe, dan untuk mengetahui kelayakan referensi dari hasil penelitian pengaruh perendaman biji kedelai dalam perasan bonggol nanas terhadap peningkatan kadar protein pada tempe. Rancangan penelitian yang digunakan adalah Rancangan Acak Lengkap (RAL) dengan 6 perlakuan dan 4 ulangan yaitu P1 (5 jam perendaman), P2 (6jam perendaman), P3 (7 jam perendaman), P4 (8 jam perendaman), P5 (9 jam perendaman) dalam perasan bonggol nanas, dan P0 (12 jam perendaman dalam aquades sebagai kontrol). Pengujian kadar protein dilakukan dengan metode Kjeldahl melalui proses destruksi, destilasi, dan titrasi yang dilakukan di Balai Pengujian dan Sertifikasi Mutu Barang (BPSMB). Analisis data kadar protein yang diperoleh menggunakan metode ANAVA dan dilakukan uji lanjut BNJ. Hasil analisis data menunjukkan adanya peningkatan kadar protein pada tempe yang direndam dengan perasan bonggol nanas pada P1 sebesar 17,39\% dan menunjukkan waktu perendaman yang paling efektif adalah 5 jam dalam perasan bonggol nanas.
\end{abstract}

Kata Kunci: Bonggol Nanas; Ananas Comosus (Linn.) Merrill; Biji Kedelai; Glycine Max (L) Merrill; Kadar Protein

\begin{abstract}
Pineapple is one of the fruits consumed by the community. Pineapple produces waste in the form of pineapple weevils which are thrown away for nothing. Pineapple weevil can be used as a medium for soaking soybeans in the process of making tempeh. The purpose of this study was to determine the effect of pineapple weevils to increase tempeh protein content, to determine the duration of soaking soybeans in pineapple cone juice which was effective in increasing tempeh protein content, and to determine the feasibility of a reference from the results of research on the effect of soaking soybean seeds in pineapple weevil juice to increase protein content in tempe. The research design used was a completely randomized design (CRD) with 6 treatments and 4 replications, namely P1 (5 hours of immersion), P2 (6 hours of immersion), P3 (7 hours of immersion), P4 (8 hours of immersion), P5 (9 hours of immersion). ) in pineapple weevil juice, and P0 (12 hours of immersion in distilled water as a control). Protein content testing was carried out using the Kjeldahl method through a process of digestion, distillation, and titration carried out at the Goods Quality Testing and Certification Center (BPSMB). Analysis of the protein content data obtained used the ANOVA method and carried out the BNJ further test. The results of data analysis showed an increase in protein content in tempeh soaked with pineapple weevil juice at P1 of $17.39 \%$ and showed that the most effective soaking time was 5 hours in pineapple weevil juice.
\end{abstract}

Keywords: Pineapple Weevil; Ananas Comosus (Linn.) Merrill; Soybean Seeds; Glycine Max (L) Merrill; Protein Content

\section{PENDAHULUAN}

Tempe merupakan salah satu makanan tradisional Indonesia yang sudah dikenal secara global. Beberapa negara seperti Amerika, Jepang dan Mesir telah memproduksi dan mengkonsumsi tempe sebagai bahan makanan. Tempe terbuat dari berbagai varietas dan warna kacang kedelai yang mengalami fermentasi oleh jamur (Nurrahman et al., 2017). Tempe adalah makanan tradisional dari Indonesia yang dibuat dari fermentasi oleh jamur Rhizopus sp pada bahan baku kedelai maupun non kedelai (Suknia \& Rahmani, 2020)). Jamur ini nantinya akan membentuk hifa. Hifa adalah benang-benang halus yang berwarna putih yang akan menumpuk di permukaan biji kedelai dan kacang merah yang nantinya akan menyatu membentuk miselium yang berwarna putih. Adanya jamur pada tempe ini dapat memproduksi beberapa enzim, misalnya enzim protease yang mampu menguraikan protein sehingga menjadi peptida yang lebih pendek serta asam amino bebas, selain itu juga dihasilkan enzim lipase yang akan menguraikan lemak sehingga menjadi asam lemak, serta juga memproduksi enzim amilase yang dapat menguraikan karbohidrat kompleks menjadi karbohidrat yang sederhana (Radiati et al., 2015).

Kedelai dikenal sebagai makanan yang bergizi tinggi serta memiliki manfaat bagi tubuh yang bisa didapatkan dengan harga murah, kandungan gizi yang terdapat dalam kedelai adalah protein, mineral, magnesium, zat besi, lemak, fosfor, karbohidrat, serat, vitamin A, vitamin B, dan isoflavon. Isoflavon yang terkandung dalam kedelai membantu menjaga daya tahan tubuh serta membantu untuk memperbaiki sel-sel tubuh yang rusak, mampu menurunkan kadar kkolesterol darah sehingga mencegah penyakit jantung (Haryono \& Kurniati, 2013).

Protein merupakan suatu zat makanan yang sangat penting bagi tubuh, karena zat ini sebagai bahan bakar dalam tubuh dan berfungsi juga sebagai zat pengatur tubuh. Protein terbentuk dari unsur-unsur organik yang hampir sama dengan karbohidrat dan lemak yaitu terdiri dari unsur karbon $(\mathrm{C})$, hidrogen $(\mathrm{H})$, dan oksigen $(\mathrm{O})$, akan tetapi ditambah dengan unsur lain yaitu nitrogen $(\mathrm{N})$. Molekul protein mengandung pula fosfor, belerang, dan ada jenis protein yang mengandung unsur logam seperti besi dan tembaga. Molekul protein tersusun dari satuan-satuan dasar kimia yaitu asam amino (Kusharto, 1992). Molekul protein yang terdapat di dalam kedelai dapat diuraikan oleh bromelin pada buah nanas.

Buah nanas merupakan sumber bromelin dan memiliki konsentrasi tinggi. Bromelin yang terdapat pada nanas dapat menghidrolisis ikatan peptida protein menjadi molekul yang lebih kecil yaitu asam amino. Asam asetat yang alami 
Journal of Pharmaceutical and Health Research

Vol 3, No 1, Februari 2022, pp. 6-9

ISSN 2721-0715 (media online)

DOI 10.47065/jharma.v3i1.1317

dan baik bagi manusia dapat ditemukan pada nanas, serta dapat memudahkan penurunan pH biji kedelai saat perendaman (Wuryanti, 2006). Industri tempe telah menjamur di Indonesia dan menjadi kebutuhan pangan pokok bagi masyarakat Indonesia. Oleh karena itu, penelitian ini penting dilakukan untuk meningkatkan kadar protein dalam tempe melalui penggunaan limbah bonggol nanas. Penelitian lain untuk meningkatkan kadar protein dengan menggunakan tepung belut (Andini et al., 2015) dan nanas (Khanifah, 2017 ). Akan tetapi belum ada studi mengenai bonggol buah nanas untuk meningkatkan kadar protein dalam tempe. Tujuan penelitian ini adalah untuk mengetahui pengaruh bonggol nanas untuk meningkatkan kadar protein tempe sehingga dapat dijadikan referensi bagi industri penghasil tempe untuk meningkatkan kadar protein di dalam tempe.

\section{METODOLOGI PENELITIAN}

\subsection{Rancangan Penelitian}

Penelitian ini termasuk dalam penelitian eksperimen. Penelitian eksperimen merupakan penelitian yang menerapkan prinsip-prinsip laboratorium. Metode ini bersifat validation, yaitu menguji pengaruh satu atau lebih variabel terhadap variabel lain (Syaodih Sukmadinata, 2010). Penelitian ini bertujuan untuk mengetahui pengaruh perendaman biji kedelai dalam perasan bonggol nanas terhadap kadar protein tempe. Rancangan yang digunakan dalam penelitian ini adalah Rancangan Acak Lengkap (RAL) dengan 6 perlakuan dan 4 ulangan yang diperoleh dari (t-1) (r-1) $\geq 15$. Adapun waktu perendaman dalam penelitian ini yang ditetapkan berdasarkan penelitian Sonja sebagai berikut (Lumowa dan Nurani, 2014):

$\mathrm{P} 0($ Kontrol $)=$ perendaman dengan air akuades selama 12 jam,

$\mathrm{P} 1=$ perendaman dengan perasan bonggol nanas selama 5 jam,

$\mathrm{P} 2=$ perendaman dengan perasan bonggol nanas selama $6 \mathrm{jam}$,

$\mathrm{P} 3$ = perendaman dengan perasan bonggol nanas selama $7 \mathrm{jam}$,

$\mathrm{P} 4=$ perendaman dengan perasan bonggol nanas selama 8 jam,

P5 = perendaman dengan perasan bonggol nanas selama 9 jam.

\subsection{Tempat dan Waktu}

Penelitian ini dilakukan di laboratorium Pendidikan Biologi Fakultas Tarbiyah dan Keguruan Universitas Islam Negeri Ar-Raniry Banda Aceh, dan laboratorium Badan Pengujian dan Sertifikasi Mutu Barang (BPSMB), pada tanggal 14 Januari 2019 - 21 Januari 2019.

\subsection{Alat dan Bahan}

Alat yang digunakan dalam penelitian ini adalah baskom, saringan, kompor, panci, timbangan analitik, labu Erlenmeyer, Labu kjeldahl, buret, kamera, alat tulis. Sedangkan bahan yang digunakan adalah biji kedelai, ragi, nanas, $\mathrm{H}_{2} \mathrm{SO}_{4}$, $\mathrm{NaOH}, \mathrm{HCl}$.

\subsection{Parameter Penelitian}

Parameter adalah ukuran atau acuan yang menjadi batas penelitian. Parameter yang diukur dalam penelitian ini yaitu kadar protein tempe.

\subsection{Teknik Analisis Data}

Data yang diperoleh dari hasil penelitian kemudian diolah dengan menggunakan Analisis Of Variance (ANAVA) secara statistik dan uji lanjut sesuai nilai KK dengan taraf kepercayaan 0,05. Analisis dihitung secara manual dan menggunakan aplikasi SPSS. Standar dalam pengambilan keputusan untuk menguji hipotesis, yaitu:

1. Apabila nilai P-Value (nilai $\mathrm{F}$ hitung) $>0,05$ maka "ada pengaruh perendaman biji kedelai dalam perasan bonggol nanas terhadap kadar protein tempe"(secara manual). Sedangkan apabila nilai sig $<0,05$ maka "ada pengaruh perendaman biji kedelai dalam perasan bonggol nanas terhadap kadar protein tempe"(aplikasi SPSS).

2. Apabila nilai $\mathrm{P}-$ Value (nilai $\mathrm{F}$ hitung) $<0,05$ maka "tidak ada pengaruh perendaman biji kedelai dalam perasan bonggol nanas terhadap kadar protein tempe"(secara manual). Sedangkan apabila nilai sig $>0,05$ maka "ada pengaruh perendaman biji kedelai dalam perasan bonggol nanas terhadap kadar protein tempe"(aplikasi SPSS).

\section{HASIL DAN PEMBAHASAN}

Hasil penelitian rata-rata kadar protein tempe biji kedelai dengan perendaman perasan bonggol nanas dapat dilihat pada Tabel 1 dibawah ini.

Tabel 1. Hasil Penelitian Kadar Protein (\%) Tempe Biji Kedelai dengan Perendaman Perasan Bonggol Nanas

\begin{tabular}{cc}
\hline Perlakuan & Rata-rata Kadar Protein \\
\hline P0 (aquades selama 12 jam) & $16.46^{\mathrm{c}}$ \\
\hline
\end{tabular}


Journal of Pharmaceutical and Health Research

Vol 3, No 1, Februari 2022, pp. 6-9

ISSN 2721-0715 (media online)

DOI 10.47065/jharma.v3i1.1317

\begin{tabular}{cc}
\hline Perlakuan & Rata-rata Kadar Protein \\
\hline P1 (Perasan bonggol nanas 5 jam) & $17.39^{\mathrm{e}}$ \\
P2 (perasan bonggol nanas 6 jam) & $17.10^{\mathrm{de}}$ \\
P3 (perasan bonggol nanas 7 jam) & $16.91^{\mathrm{d}}$ \\
P4 (perasan bonggol nanas 8 jam) & $15.47^{\mathrm{b}}$ \\
P5 (perasan bonggol nanas 9 jam) & $14.60^{\mathrm{a}}$ \\
\hline
\end{tabular}

Keterangan : superskrip huruf kecil menunjukkan bahwa hasil berbeda nyata $(\mathrm{P}>0.05)$

Berdasarkan data pada tabel 1 diperoleh kadar protein rata-rata hasil perendaman yaitu, perendaman aquades 24 jam (P0) sebesar 16.46\%, perendaman perasan bonggol nanas 5 jam (P1) sebesar $17.39 \%$, perendaman perasan bonggol nanas 6 jam sebesar (P2) $17.10 \%$, perendaman perasan bonggol nanas 7 jam (P3) sebesar 16.93\%, perendaman perasan bonggol nanas 8 jam $\mathrm{P}(4)$ sebesar $15.47 \%$, dan perendaman perasan bonggol nanas 9 jam (P5) sebesar $14.60 \%$. Berdasarkan rata-rata tersebut dapat dilihat bahwa perendaman yang memiliki nilai kadar protein yang paling tinggi adalah pada perendaman P1, sedangkan perendaman yang memiliki kadar protein terendah adalah pada perendaman P5.

Kadar protein tempe pada tabel 1 menunjukkan bahwa kadar protein P2 tidak berbeda nyata dari P1 dan P3, hal ini disebakan karena buah nanas yang masih hijau atau belum matang memiliki enzim bromelin lebih rendah dibandingkan dengan nanas yang sudah matang (Murniati, 2006). Kadar protein perlakuan perasan bonggol nanas selama 5 jam paling tinggi dibandingkan dengan perlakuan lainnya. Pemanfaatan enzim bromelin pada pembuatan tempe berprinsip pada kemampuan bonggol nanas untuk membuat suasana asam yang pas bagi pertumbuhan jamur tempe. Suasana asam atau $\mathrm{pH}$ yang pas bagi pertumbuhan jamur tempe sendiri berkisar antara 4 sampai 5. Suasana asam dapat diperoleh dari perendaman bonggol nanas.

Menurunnya kadar protein pada tempe ini disebut dengan denaturasi protein. Denaturasi dapat diartikan sebagai satu perubahan atau modifikasi terhadap struktur molekul protein. Faktor-faktor yang dapat menyebabkan terjadinya denaturasi protein yaitu suhu tinggi, perubahan $\mathrm{pH}$ yang ekstrim, pelarut organik, zat kimia tertentu atau pengaruh mekanik (guncangan) (Kusnandar et al., 2011).

Terdapat perbedaan antara kadar protein tempe dengan menggunakan kulit nanas berdasarkan penelitian Lumowa dan Nurani (2014), pada penelitian Lumowa dengan menggunakan kulit nanas kadar protein tempe pada perendaman 6 jam menunjukkan hasil yaitu 22.73\%.75 Sedangkan berdasarkan hasil penelitian menggunakan bonggol nanas kadar protein pada perendaman 6 jam menunjukkan hasil 17.10\%. Hal ini disebabkan karena perbedaan kandungan kimia pada kulit dan bonggol, kandungan asam asetat lebih menonjol pada kulit nanas, sedangkan pada bonggol nanas enzim bromelin lebih menonjol.

Data yang diperoleh dari lapangan kemudian dianalisis menggunakan ANAVA (analisis varian) untuk menguji hipotesis penelitian. Berdasarkan tabel 1 dapat dilihat bahwa $\mathrm{F}$ hitung lebih besar dibandingkan $\mathrm{F}$ tabel, yang mana $\mathrm{F}$ hitung adalah 45.272 sedangkan $F$ tabel adalah 2.77. jika $F$ hitung lebih besar dari $F$ tabel maka dapat disimpulkan bahwa diterimanya Ha dan ditolaknya H0. Jadi, terdapatnya pengaruh penggunaan perasan bonggol nanas terhadap kadar protein tempe, hal ini juga menjawab rumusan masalah pertama

Setelah diuji ANAVA kemudian diuji BNJ untuk mengetahui tingkat perbedaan nyata dari masing-masing perlakuan dapat dilihat pada tabel 4.3, yang mana kadar protein tempe perlakuan P2 tidak berbeda nyata dengan P1, dan P3. Sedangkan kadar protein tempe perlakuan P5 berbeda nyata dengan perlakuan P4, P0, P3, P2 dan P1. Melalui tabel 4.3 dapat diketahui lama perendaman biji kedelai dalam perasan bonggol nanas yang paling efektif meningkatkan kadar protein pada tempe adalah perlakuan P1 dengan lama perendaman 5 jam.

\section{KESIMPULAN}

Berdasarkan hasil penelitian pengaruh perendaman biji kedelai dalam perasan bonggol nanas terhadap kadar protein pada tempe yang telah dilakukan dapat disimpulkan bahwa adanya pengaruh perendaman biji kedelai dalam perasasn bonggol nanas terhadap kadar protein pada tempe, yang ditunjukkan pada data anava yaitu, F hitung 45.272 lebih besar dari $\mathrm{F}$ tabel taraf signifikan 5\% yaitu 2.77. Perendaman biji kedelai dalam perasasn bonggol nanas terhadap kadar protein pada tempe yang paling efektif adalah pada perendaman perasan bonggol nanas selama 5 jam (P1) yang memiliki nilai rata-rata kadar protein yang paling tinggi diantara perlakuan lainnya yaitu sebesar 17.39\%.

\section{DAFTAR PUSTAKA}

Andini, S., Virginia, G., \& Hartini, S. (2015). PENINGKATAN KADAR PROTEIN, LEMAK, DAN ASAM LEMAK TAK JENUH PADA TEMPE AKIBAT PENAMBAHAN TEPUNG BELUT (Monopterus albus zuieuw) DAN UJI SENSORIS TEMPE BELUT. Jurnal Teknologi Pangan Dan Hasil Pertanian, 12(1), 32-43. https://doi.org/10.26623/JTPHP.V12I1.480

Haryono, B., \& Kurniati, D. (2013). Seri Tanaman... - Google Cendekia. (n.d.). Retrieved February 28, 2022, from https://scholar.google.com/scholar?hl=id\&as_sdt=0\%2C5\&q=Haryono\%2C+B.\%2C+\%26+Kurniati\%2C+D.+\%282013\%29.+ Seri+Tanaman+Bahan+Baku+Industri+TEH\%2C+Jakarta\%3A+PT.+Trisula+Adisakti.\&btnG=

Khanifah, F. (2018). Analisis Kadar Protein Total pada Tempe Fermentasi dengan Penambahan Ekstrak Nanas (Ananascomosus (L.) Merr ) - STIKES Insan Cendekia Medika Repository. (n.d.). Retrieved February 28, 2022, from http://repo.stikesicme- 


\title{
Journal of Pharmaceutical and Health Research
}

\author{
Vol 3, No 1, Februari 2022, pp. 6-9
}

ISSN 2721-0715 (media online)

DOI 10.47065/jharma.v3i1.1317

jbg.ac.id/1819/

Kusnandar, F., Andarwulan, N., \& Herawati, D. (2011)... - Google Cendekia. (n.d.). Retrieved February 28, 2022, from https://scholar.google.com/scholar?hl=id\&as_sdt=0\%2C5\&q=Kusnandar\%2C+F.\%2C+Andarwulan\%2C+N.\%2C+\%26+Hera wati\%2C+D.+\%282011\%29.+Analisis+Pangan.+Jakarta\%3A+Dian+Rakyat.\&btnG=

Lumowa SVT dan Nurani I. (2014). PENGARUH PERENDAMAN BIJI KEDELAI (Glycine max, L. Merr) DALAM MEDIA PERASAN KULIT NANAS (Ananas comosus (Linn.) Merrill) TERHADAP KADAR PROTEIN PADA PEMBUATAN TEMPE. Jurnal EduBio Tropika, 2(2), 230-236.

Murniati, E. (2006). Sang Nanas bersisik Manis di... - Google Cendekia. (n.d.). Retrieved February 28, 2022, from https://scholar.google.com/scholar?hl=id\&as_sdt=0\%2C5\&q=Murniati\%2C+E.+\%282006\%29.+Sang+Nanas+bersisik+Manis + di+Lidah'.+Percetakan+SIC\%3A+Surabaya. $+\% 09 \& b$ tnG $=$

Nurrahman, M., Agritech, M. S.-, (2012). PERTUMBUHAN JAMUR, SIFAT ORGANOLEPTIK DAN AKTIVITAS ANTIOKSIDAN TEMPE KEDELA HIITAM YANG DIPRODUKSI DENGAN BERBAGAI JENIS. I-Lib.Ugm.Ac.Id. Retrieved February 28, 2022, from http://i-lib.ugm.ac.id/jurnal/detail.php?dataId=11653

Radiati, A., Pangan, S. S.-J. A. T., (2015). Analisis sifat fisik, sifat organoleptik, dan kandungan gizi pada produk tempe dari kacang non-kedelai. Jatp.Ift.or.Id. Retrieved February 28, 2022, from http://www.jatp.ift.or.id/index.php/jatp/article/view/32

Suknia, S. L., \& Rahmani, T. P. D. (2020). Proses Pembuatan Tempe Home Industry Berbahan Dasar Kedelai (Glycine max (L.) Merr) dan Kacang Merah (Phaseolus vulgaris L.) Di Candiwesi, Salatiga. Southeast Asian Journal of Islamic Education, 03(01), 5976.

Syaodih Sukmadinata, N. (2010). Metode Penelitian... - Google Cendekia. (n.d.). Retrieved February 28, 2022, from https://scholar.google.com/scholar?hl=id\&as_sdt=0\%2C5\&q=Syaodih+Sukmadinata\%2C+N.+\%282010\%29.+Metode+Penelit ian+Pendidikan\%2C+Bandung\%3A+PT.+Remaja+Rosda+Karya+Offset.\&btnG=

Wuryanti W. (2006). Amobilisasi Enzim Bromelin dari Bonggol Nanas dengan Bahan Pendukung (Support) Karagenan dari Rumput Laut (Euchema cottonii). Ejournal.Undip.Ac.Id. Retrieved February 28, 2022, from https://ejournal.undip.ac.id/index.php/ksa/article/view/3284 